Лихвенко С. П., старший викладач, Харак Р. М., кандидат технічних наук Полтавська державна аграрна академія

\title{
ЕКСПЕРИМЕНТАЛЬНЕ ДОСЛІДЖЕННЯ СТІЙКОСТІ ПРЯМОЛІНІЙНОГО РУХУ ТРАКТОРА В УМОВАХ РІЗНОГО ЗЧЕПЛЕННЯ ВЕДУЧИХ КОЛІС
}

\section{Рецензент - кандидат технічних наук О. В. Іванкова}

\begin{abstract}
Представлені результати експериментального дослідження стійкості прямолінійного руху трактора МТ3-80 у проиесі роботи на поверхні з різним зчепленням коліс і постійному навантаженні на гаку залежно від швидкості руху. Встановлено, щзо для забезпечення прямолінійного руху при диферениіальному приводі коліс заднього моста необхідно повертати передні колеса трактора в середньому на кут 2,18 ${ }^{\circ}$, а при жорстко блокованому привод $i$ - на 5,16 ${ }^{\circ}$. Кут повороту коліс збільшується при зростанні швидкості руху трактора. Вимірювання параметрів здійснювалось із використанням тензометричних пристроїв.
\end{abstract}

Ключові слова: диференціал, блокування, кут повороту, обертаючий момент, коефіиієнт блокування, колесо, зчеплення.

Постановка проблеми. За умов руху трактора по дорозі з неоднорідним станом поверхні, коли одне колесо може опинитися в умовах гарного зчеплення, а інше потрапляє на слизьку ділянку, диференціальний міжколісний привід призводить до погіршення прохідності й зменшення швидкості руху внаслідок реалізації сумарного обертаючого моменту на ведучих колесах за мінімальним значенням їх зчеплення 3 опорною поверхнею. Блокування міжколісного диференціала суттєво покращує прохідність і збільшує швидкість руху внаслідок реалізації обертаючого моменту відповідно до умов зчеплення кожного колеса. В той же час (внаслідок перерозподілу ведучого моменту між колесами) виникає момент, що відхиляє трактор від прямолінійного руху [3], для забезпечення якого в таких умовах необхідно повертати керовані колеса на певний кут.

Аналіз останніх досліджень i публікацій, у яких започатковано розв'язання проблеми. Аналіз публікацій із даного питання $[2,3]$, дає підставу дійти висновку, що в теоретичному плані керованість трактора в умовах різного зчеплення коліс з опорною поверхнею, особливо на транспортних роботах, достатньо обгрунтована, але відсутні експериментальні дослідження. Автори публікацій [3] відзначають, що блоку- вання міжколісного диференціалу за умов різного зчеплення коліс забезпечує збільшення швидкості руху трактора внаслідок зростання обертаючого моменту на колесі, що знаходиться на поверхні з кращим зчепленням і зменшення буксування. В свою чергу, згідно джерела [3], перерозподіл обертаючих моментів між колесами одного моста призводить до погіршення керованості трактора внаслідок виникнення моменту, що відхиляє трактор від прямолінійного руху. Для утримання трактора у напрямку прямолінійного руху необхідно повертати керовані колеса на певний кут, що призводить до збільшення сил опору коченню і зменшення тягового к.к.д. [2].

Мета дослідження. Мета дослідження - визначення умов забезпечення стійкості прямолінійного руху трактора на поверхнях із різним зчепленням для отримання експериментальних даних, які б підтвердили теоретичні обгрунтування. Для цього нами проведені дослідження (згідно 3 договором із Мінським тракторним заводом [1]) на попередньо підготовлених ділянках дороги з використанням трактора МТЗ-80.

Матеріали і методи досліджень. Для лівих коліс забезпечувалося покриття у вигляді сухого асфальту, а для правих - у вигляді льоду. Рух трактора здійснювався на 3-ій, 5, 7, 8 і 9-ій передачах із навантаженням на гаку $\mathrm{P}_{\Gamma}=3,5 \ldots 3,8$ кН. Таке навантаження дає можливість руху трактора на транспортних передачах і забезпечується за допомогою буксирного трактора МТ3-80. Сила тяги на гаку вимірювалася за допомогою тензометричного динамометра.

У зв'язку зі змінними умовами зчеплення встановити ідентичні навантаження на гаку при рухові з заблокованим і розблокованим диференціалом заднього моста трактора дослідникам не вдалося. Прямолінійність руху трактора забезпечувалася поворотом керованих (передніх) коліс на певний кут.

У процесі досліджень вимірювалися значення обертаючого моменту на півосях заднього мосту трактора лівого $\mathbf{M}_{к л}$ і правого $\mathbf{M}_{\text {кп }}$ коліс, кут по- 
вороту передніх коліс (середній $\boldsymbol{\alpha}$ та максимальний $\boldsymbol{\alpha}_{\text {мах }}$ ), швидкість руху трактора $\boldsymbol{v}$. Усі параметри вимірювалися 3 використанням тензометричних пристроїв і записувались на осцилограму 3 використанням мобільної тензометричної лабораторії на базі автомобіля ГАЗ-53А.

Результати досліджень. Значення вимірюваних та аналітично визначених показників, отриманих після обробки осцилограм та їх аналізу i складання звіту [1], представлені в таблиці1.

Аналітично визначалися показники: різниця обертаючих моментів
$\Delta \mathrm{M}_{\mathrm{K}}=\mathrm{M}_{\text {кл }}-\mathrm{M}_{\mathrm{кп}}$,

сумарний обертаючий момент

$\mathrm{M}_{\mathrm{K}}=\mathrm{M}_{\text {кл }}+\mathrm{M}_{\mathrm{\kappa п}}$,

коефіцієнт блокування диференціалу

$$
\mathrm{K}_{\text {б }}=\mathrm{M}_{\text {кл }} / \mathrm{M}_{\text {кп }} \text {. }
$$

3 розблокованим диференціалом, на восьмій і дев'ятій передачах мало місце значне буксування правого колеса, що знаходилось на льоду, внаслідок чого швидкість руху трактора не перевищувала 2,47 м/с (табл. 1).

\section{1. Значення динамічних показників і кута повороту керованих коліс трактора МТЗ-80} на дорозі з різним зчепленням

\begin{tabular}{|c|c|c|c|c|c|c|c|c|c|}
\hline Привід & Передача & $\begin{array}{c}\mathrm{V}, \\
\mathrm{M} / \mathrm{c}\end{array}$ & $\begin{array}{l}\mathrm{M}_{\mathrm{k},}, \\
\mathrm{KH} \cdot \mathrm{M}\end{array}$ & $\begin{array}{l}\mathrm{M}_{\text {кп, }} \\
\mathrm{\kappa H} \cdot \mathrm{M}\end{array}$ & $\begin{array}{l}\Delta \mathrm{M}_{\mathrm{K}}, \\
\mathrm{KH} \cdot \mathrm{M}\end{array}$ & $\mathrm{M}_{\mathrm{K}}, \mathrm{KH} \cdot \mathrm{M}$ & $\mathrm{K}_{\sigma}$ & $\alpha,^{0}$ & $\alpha_{\text {мax }},{ }^{0}$ \\
\hline \multirow{6}{*}{$\begin{array}{l}\text { Диферен- } \\
\text { ціальний }\end{array}$} & 3 & 1,61 & 3,09 & 1,40 & 1,69 & 4,49 & 2,21 & 1,7 & 3,5 \\
\hline & 5 & 2,31 & 3,02 & 1,13 & 1,89 & 4,15 & 2,67 & 2,0 & 4,7 \\
\hline & 7 & 2,83 & 3,02 & 1,13 & 1,89 & 4,15 & 2,67 & 2,1 & 6,7 \\
\hline & 8 & 2,47 & 1,92 & 1,12 & 0,80 & 3,04 & 1,71 & 2,4 & 4,0 \\
\hline & 9 & 2,47 & 2,40 & 0,91 & 1,49 & 3,31 & 2,64 & 2,7 & 4,7 \\
\hline & $\begin{array}{c}\text { Середнє } \\
\text { значення }\end{array}$ & 2,34 & 2,69 & 1,14 & 1,55 & 3,83 & 2,38 & 2,18 & 4,72 \\
\hline \multirow{6}{*}{ Блокований } & 3 & 1,61 & 2,75 & 0,28 & 2,47 & 3,03 & 9,82 & 4,0 & 6,2 \\
\hline & 5 & 2,33 & 1,51 & 0,30 & 1,21 & 1,81 & 5,03 & 4,1 & 4,7 \\
\hline & 7 & 3,36 & 1,92 & 0,30 & 1,62 & 2,22 & 6,40 & 4,5 & 9,2 \\
\hline & 8 & 3,92 & 2,13 & 0,42 & 1,71 & 2,55 & 5,07 & 5,0 & 10,7 \\
\hline & 9 & 5,19 & 4,67 & 0,91 & 3,76 & 5,58 & 5,13 & 8,2 & 17,7 \\
\hline & $\begin{array}{c}\text { Середнє } \\
\text { значення }\end{array}$ & 3,08 & 2,60 & 0,44 & 2,15 & 3,04 & 6,29 & 5,16 & 9,70 \\
\hline
\end{tabular}
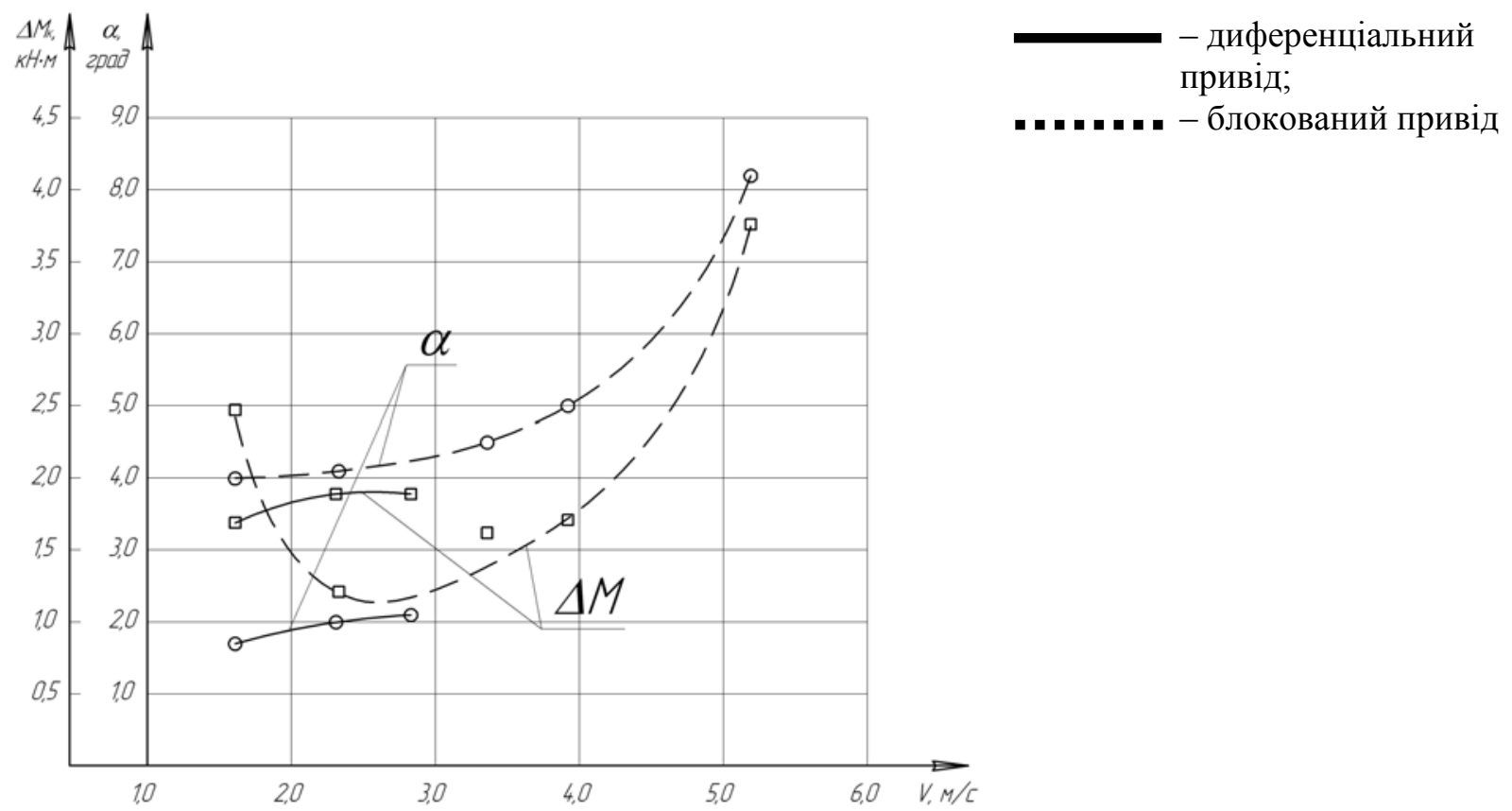

Рис. 1. Залежність кута а повороту керованих коліс трактора та різниці обертаючих моментів $\triangle M$ від швидкості руху $V$ 
У тракторі із заблокованим диференціалом для забезпечення прямолінійного руху необхідно повертати керовані колеса на кут від $4^{0}$ (при швидкості 1,61 м/с), до $8,2^{0}$ - при швидкості 5,19 м/с. Середній кут повороту керованих коліс становить $5,16^{0}$, а максимальний $-17,7^{0}$. Спостерігається чітка тенденція збільшення кута повороту керованих коліс із зростанням швидкості, що видно з графіків (див. рис.).

У диференціальному приводі при зростанні швидкості трактора кут повороту керованих коліс змінювався від $1,7^{0}$ до $2,7^{0}$, тобто був незначним. Це пояснюється меншою різницею обертаючих моментів між півосями (середнє значення $\left.\Delta \mathrm{M}_{\mathrm{K}}=1,55 \mathrm{\kappa H} \cdot \mathrm{M}\right)$, а середнє значення кута повороту керованих коліс становить $2,18^{\circ}$. Різниця обертаючих моментів між колесами (середній коефіцієнт блокування диференціала $\left.\mathrm{K}_{\sigma}=2,38\right)$ пояснюється підвищеним внутрішнім тертям у диференціалі в зв'язку з виконанням дослідів за низьких температур навколишнього середовища.

У заблокованому диференціалі значення моментів на ведучому колесі 3 максимальним зчепленням (асфальт) були в 5-9 разів більші, ніж моменти на колесі з меншим зчепленням (лід). Відповідно, був більший відхиляючий момент трактора, і для його подолання необхідно повертати керовані колеса на більший кут у бік того колеса, на якому був менший момент. У разі диференціального приводу співвідношення моментів зменшувалося до 2-3, тобто в середньому у 2,64 разу (див. табл.). Зростання швидкості руху трактора $з$ розблокованим диференціалом спостерігалося тільки до сьомої передачі, а на восьмій і дев'ятій швидкість внаслідок інтенсивного буксування становила $2,47 \mathrm{~m} / \mathrm{c}$.

Швидкість руху трактора по передачах при заблокованому диференціалі була суттєво вища, ніж при розблокованому (особливо на 7, 8 і 9 передачах) внаслідок кращого використання зчеплення, що зменшило буксування. Середня

\section{БІБЛІОГРАФІЯ}

1. Исследование тягово-сцепных свойств и управляемости колесного трактора кл. 1,4 тс с автоблокирующимся дифференциалом: Отчет о НИР / Полтавск. сельхозинститут - МТЗ. - № 517. - Полтава, 1973. - С. 29-33.

2. Кутьков Г. М. Тяговая динамика тракторов. - швидкість руху (диференціальний привід) становила 2,34 м/с, а при блокованому $-3,08 \mathrm{~m} / \mathrm{c}$, тобто збільшилася на 24,03\%. Середнє значення сумарного обертаючого моменту $\mathrm{M}_{\mathrm{K}}$ при рухові 3 диференціальним приводом було на 20,63 \% більше, ніж при блокованому.

Значення бокових сил на керованих колесах, які теж вимірювалися у процесі випробування трактора (рух із заблокованим диференціалом), у середньому в $1,5-2,0$ рази перевищували ці ж сили при диференціальному приводі, що пояснюється більшим кутом повороту керованих коліс при блокованому приводі для урівноваження дії відхиляючого моменту ведучих коліс. Це призводить до зменшення тягового коефіцієнта корисної дії трактора внаслідок зростання втрат на переборення сил опору коченню трактора [2], бо керовані колеса повернуті на більший кут.

\section{Висновки:}

1. Порівнюючи обидва види руху трактора, можна зробити висновок, що при блокованому міжколісному приводі, в зв'язку з більш значним (у 2,64 разу) перерозподілом обертаючого моменту між ведучими півосями, кут повороту керованих коліс для забезпечення прямолінійного руху в 2-3 рази більший, ніж при диференціальному приводі. Таким чином, при блокованому приводі для переборення ділянок дороги, на якій можливе одночасно максимальне і мінімальне зчеплення співвісних ведучих коліс, керованість трактора погіршується, зате значно покращується прохідність.

2. Тяговий коефіцієнт корисної дії трактора при блокованому приводі зменшується через зростання втрат на переборення сил опору коченню трактора.

3. У наступних дослідженнях доцільно детальніше встановити вплив різнорідного зчеплення коліс $з$ опорною поверхнею на тягово-зчіпні показники трактора 3 різними сільськогосподарськими знаряддями.

М.: Машиностроение, 1980.-321 с.

3. Мельников Д. И., Стеиько П. А. Исследование распределения момента по ведущим колесам трактора с блокирующимся дифференциалом при движении по снежным дорогам // Тр. Харьк. с.х. ин-та. - Т. 174. - Х., 1972. - С. 46-48. 